\title{
WORDS AND MUSIC
}

\author{
A performance of note.
}

\section{BY RONALD D. FERGUSON}

$\mathrm{Y}$ eah, you got me, fair and square. I didn't think you'd recognize me. I am the government translator, the guy who lurks off the shoulder of Space Systems' chief negotiator and whispers connotations, corrections and culpability in case the computer renders too literal a verdict on Utmano phrasing. I've got nothing to do with speakos. Talk with the programmers for input-output problems.

I hope you're recording this, because it will be my only interview. Please, just a few questions, so quit yelling. I'll tell the story, and then I go home. Understood?

Here's what happened. The meeting began with the formal greeting...

Example? You want to know what the Utmano said? Do you speak Utmano? Oh, the literal translation into English? Right. Let me see...

It is beautiful weather we shall be having tomorrow wasn't it?

That's not the literal translation of the Utmano greeting, but that's as close as I'm likely to get on a Tuesday. Today is Wednesday? No, I can't do better today. Of course, the literal translation isn't what the Utmano meant. From the variations of pitch within the context of the meeting, my best interpretation is:

We should complete negotiations successfully tomorrow based on the current tolerant atmosphere and previously adopted ground rules.

The computer's translation was close, possibly better based on pitch and less accurate where context was important. Diphthong? No pitch, like I said. Intonation would be a reasonable description. Thai is the human intonation language that comes to mind, but Utmano is like intonation on steroids. Spoken Utmano must be sung.

No, I don't think an Utmano looks like a whale. That's uncalled for.

Speak Utmano? Unaided, I cannot speak Utmano. My base vocabulary is okay, and I might squeeze out a few words, but the Utmano tonal range is 14 octaves. They have some vocabulary modifiers well above 20,000 hertz, which is likely to make your neighbour's dog bark. Humans have a more limited range. I use a synthesizer to ...

Human range? Oh, I don't know. If you watch old videos, Julie Andrews had a fouroctave range, Mariah Carey perhaps five, but most people can't do that. I certainly can't.
I'm good at listening to the symphony that Utmano call speech. I'm not Mozart, but I have a good ear, and training as a professional musician.

No, Julie Andrews. You know, The Sound of Music. Okay?

Symphony? Each Utmano has a double set of vocal chords and can sound two notes at once. An Utmano can sing harmony with itself. The Utmano divide an octave into 32 parts. That's why we rely on computers and Fourier analysis...

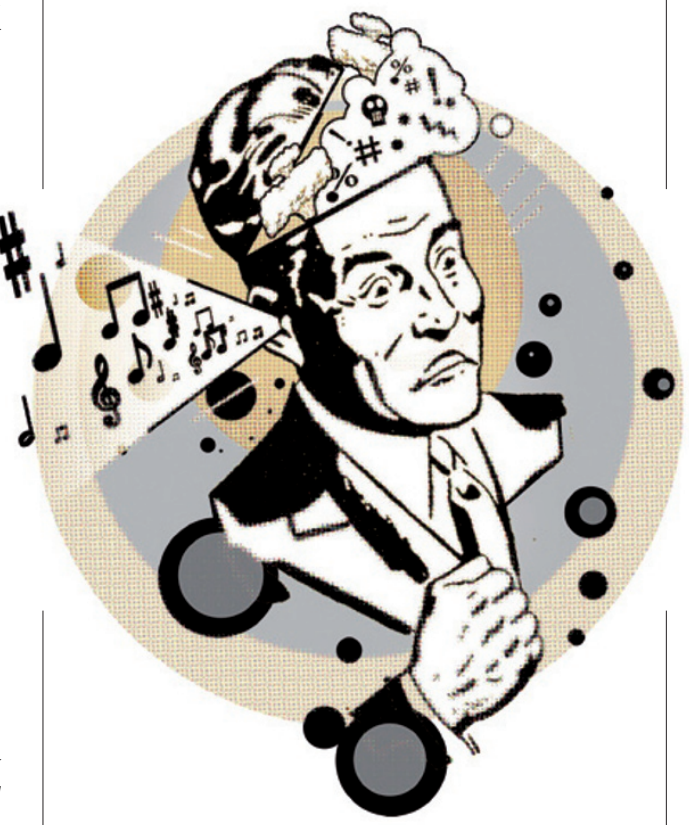

No. I understand your question, but Utmano translation doesn't compare well to translations among human languages. The Utmano language has a peculiar view of tense, you know, past, present, future, in its sentences - well maybe not sentences, but the complete-thought communication structure. Psychologists claim that the Utmano have a lingering, vivid, recent memory combined with a mild prescience that blends with their perception of the 'now'. It sounds like gobbledegook, but they claim that the Utmano idea of the present spans from the middle of last week to a couple of hours from now.

In translating from English to Greek, or French, or whatever Earth language you $\rightarrow$ NATURE.COM

Follow Futures on

Facebook at:

go.nature.com/mtoodm pick, we have the advantage of common human experiences. Humans share uncommonly little with the Utmano.
No. I'm not making excuses. I accept the blame for missing any subtle nuance, but the Utmano response was undocumented. Google the literature, and the only violent reactions are for personal insults...

I'll stick to the topic. I repeat for the record. Intonation is not a critical characteristic of most human languages, but to the Utmano, a change in pitch is an essential communication detail.

Look, I've got to go. I need to finish this interview. I can't give any details of the ongoing negotiations, because those are secret. I can confirm the official report. Yes, I know the report is short. Do you have a 학 copy? Okay, I'll read it for those in the back.

"Chief Negotiator Simon Mann died today when he bade farewell to the Utmano Ambassador. A focused eruption of sonic energy homogenized Dr Mann's brain. With no hope for recovery, his family directed he be removed from life support."

You heard that the sonic energy was a blast of rage from the Utmano Ambassador? No. I cannot confirm that. Yes, I was there, but appearances aren't always reality.

Yes, I was told that Dr Mann practised a few phrases in Utmano. No, I didn't coach him. I was never asked to coach him. Besides, I use the very tedious process of keyboarded voice modulation when I speak Utmano. Dr Mann wasn't a musician, and I wouldn't know how to coach him. I certainly didn't know that Dr Mann planned to speak in Utmano or I would have advised against it.

What? John Kennedy at the Berlin Wall, the 'Ich bin ein Berliner' speech? Yeah, I've seen the newsreel. No, I don't think Kennedy said 'I'm a jelly doughnut.' No, I don't know whether Dr Mann planned to run for elected office.

Negotiations? Negotiations will resume in two weeks, once we are well past the Utmano concept of the present. No, I don't believe that is 'pout time' or 'holding a grudge'.

One last question? Okay, you, in the back. Did Dr Mann make a mistake? All I've got is my humble opinion, not as a translator, but as a musician.

Like many tone-deaf amateurs, he thought he could sing. $\square$

Ronald D. Ferguson has decided that writing fiction is more fun than writing college textbooks. He lives with his wife and five feral cats on two acres of the Texas Hill Country. 